\title{
PENERAPAN MANAJEMEN KRISIS DI INDONESIA : MEMOTRET KRISIS DALAM KACAMATA PUBLIC RELATIONS
}

\author{
Marsefio S. Luhukay \\ Jurusan Ilmu Komunikasi, Fakultas Ilmu Komunikasi, \\ Universitas Kristen Petra \\ Jalan Siwalankerto 121-131 Surabaya 60236 \\ email: ashandy@peter.petra.ac.id
}

\begin{abstract}
Public relations as a proactive management function, which performs the effort of monitoring trends, events, issues that may arise and distract the important relationships in a company. The continuous monitoring effort done by the Public Relations through informal relationship, and others, may give big benefit to the company when the crisis occurs. That's why, PR can be said to be the portrait of the company. It is the eyes, ears and at the same time, the speaker for the organization. When an organization trembles, $P R$ stands forward, when organization at a stable condition, it remains diligent in research and analysis, when a company moves forward, it stands behind, supports all organization's supporting activity and programs. In other words, Public Relations is a must. When a crisis occurs, $P R$ exists as a facilitator and mediator between organization and it's public. That's why I emphasized in my preamble's argumentation that PR is highly needed in an organization, especially in Indonesia which, from my point of view, still gives meaning and locates PR in a highly different position as it is supposed to be.
\end{abstract}

Keywords: pr, management function

\section{PENDAHULUAN}

Krisis dapat terjadi dimana saja dan kapan saja, pada siapa saja. Krisis tidak pernah memandang bulu ataupun pilih-pilih kasih. Krisis bisa datang tanpa menunggu kesiapan kita. Dan ketika krisis yang tidak pernah diperhitungkan terjadi, semua menjadi bingung, tanpa arah, dan kehilangan kendali. Begitu pula dalam suatu perusahaan atau organisasi. Ketika terjadi krisis, maka seluruh aktivitas organisasi bisa menjadi lumpuh. Terutama jika krisis yang terjadi adalah krisis dalam skala yang cukup besar. Semua komponen dalam suatu perusahaan merasakan akan dampaknya. Mengingat organisasi sebagai suatu system, yang tidak bisa terlepas begitu saja dari lingkungannya.

Adapun lingkungan pembentuk organisasi ada 2 (dua) yakni internal dan eksternal. Lingkungan eksternal merupakan lingkungan diluar organisasi yang turut berperan dalam pembentukan organisasi tersebut. Kemajuan organisasi, perkembangan organisasi tidak terlepas dari lingkungan eksternalnya. Sementara lingkungan dalam organisasi adalah komponen yang sangat dekat dengan organisasi. Mereka inilah yang mensupport organisasi siang dan malam, bekerja 
tanpa leltih untuk kemajuan organisasi. Lingkungan-lingkungan ini yang menjadi public dalam organisasi, public inilah yang sangat dekat dengan Public Relations.

Public Relations sendiri, belumlah menjadi pilihan utama bagi organisasi. Public Relations masih hadir dan menjadi pilihan dari beberapa pilihan lainnya, bahkan terkadang tidak dipilih, karena dianggap merugikan perusahaan jika ada tambahan komponen lain yang belum tentu mendatangkan manfaat yangbesar bagi organisasi. Tetapi apakah hal ini benar? belum tentu juga. Public Relations hadir dalam organisasi bukan suatu kebetulan, tetapi ia hadir sebagai suatu kebutuhan. Kebutuhan yang terkadang diabaikan dan seperti yang saya katakan sebelumnya, tidak menjadi pilihan. Tetapi, ketika krisis terjadi, ketika datang masalah, misalnya media yang memblow up berita perusahaan tersebut di Koran lokal dan nasional tentang salah satu produk unggulan perusahaan yang dihubungkan dengan kematian konsumen, atau ada demonstrasi pekerja terkait kebijakan perusahaan, ada krisis yang besar misal kecelakaan pesawat terbang yang menewaskan ratusan orang, bencana alam, eksploitasi produksi pabrik dalam skala besar yang mengakibatkan kerusakan lingkungan, surat pembaca yang "mengharu biru" yang isinya memusuhi perusahaan dan produknya, kekecewaan karyawan yang pensiun karena dana pensiun yang diperoleh tidak sesuai kesepakatan, demonstrasi warga sekitar karena limbah industri perusahaan yang membawa penyakit bagi warga, keresahan warga sekitar karena perusahaan yang tidak memperkerjakan komunitas sekitar sebagai karyawan lapangan, dosen yang resah karena gaji belum disesuaikan sesuai janji dari Universitas yang akibatnya mutu perguruan tinggi itu menjadi menurun karena dosen yang berkurang komitemen mengajar dan mengabdi, bencana banjir, tsunami didaerah lokasi pabrik /opersional perusahaan, dan sederet krisis lainnya, membuat perusahaan pontang-panting mencari Public Relations, yang dianggap sebagai solusi.

Ada yang menempuh cara menggunakan jasa konsultan PR, ada yang menggunakan tim PR "dadakan" dari internal organisasi, ada pula yang yang mengganggap Marketing sebagai PR dan ada yang langsung membuka lowongan mencari staf PR. Sungguh suatu upaya yang sia-sia. Seolah-olah Public Relations bukanlah suatu profesi yang memiliki kode etik tersendiri, profesi yang ditekuni setelah melampaui jenjang pendidikan tertentu. Profesi yang menuntut ketajaman analisis dan daya kreativitas yang tinggi. PR hanya dipandang sebagai pelengkap penderita ketika terjadi krisis.

Padahal Public Relations adalah suatu proses. Bukan dilakukan mendadak, bukan dilakukan tanpa perencanaan, bukan dilakukan dalam semalam. Public Relations hadir sebagai suatu kebutuhan, kebutuhan untuk menjembatani organisasi dengan para pemangku kepentingan (stakeholders) dan bahkan lebih jauh lagi dengan para investor dan shareholders. Jembatan yang dibangun PR bukanlah jembatan keledai, tetapi jembatan yang sungguh-sungguh kokoh, berdiri atas dasar Trust, Honest dan Credibility. Public Relations ada,karena ada Kepercayaan. Artinya masyarakat percaya pada organisasi dan organisasi percaya pada masyarakat atas dasar saling pengertian dan win-win solution. PR membangun citra dan reputasi organisasi lewat opini public yang menguntungkan (favourable) melalui kaca mata public yang memotret aktivitas organisasi di media massa. Lewat citra dan reputasi, organisasi tetap dapat berdiri kokoh dalam ranah kompetisi yang sangat tajam 
merebut pangsa pasar dan konsumen yang loyal pada produk dan servis dari organisasi.

Sekali lagi, Public Relations adalah potret dari organisasi. Ia menjadi mata, telinga sekaligus corong bagi organisasi. Ketika organisasi goyah, PR yang maju kedepan, ketika organisasi berada dalam posisi aman-aman saja, ia tetap tekun melakukan riset dan analisis, ketika perusahaan maju, ia berdiri dibelakang, mensupport semua aktivitas dan program yang mendukung organisasi. Dengan kata lain, Public Relations is a must.

Begitu pula ketika krisis datang, PR ada untuk menjadi fasilitator dan mediator antara organisasi dan publiknya. Itulah mengapa saya menekankan dalam argumentasi saya dipendahuluan bahwa PR sangat diperlukan dalam organisasi, terutama organisasi di tanah air kita yang menurut pandangan saya masih sangat jauh berbeda mengartikan PR dan menempatkan PR dalam posisi yang seharusnya ia berada.

\section{PEMBAHASAN}

Public Relations, seperti yang kita ketahui, merupakan fungsi manajemen proaktif yang melakukan upaya memantau trends, kejadian, issue-issue yang dapat timbul dan menganggu hubungan-hubungan penting di perusahaan. Upaya pemantauan secara kontinyu yang dilakukan oleh Public Relations melalui hubungan informal, dan lain-lain, akan memberikan manfaat yang besar pada perusahaan ketika krisis terjadi.

\section{Beberapa Definisi Public Relations}

The British Institute of Public Relations memberikan definisi sebagai berikut:

"Public relations practice is the deliberate, planned and sustained effort to establish and maintain mutual understanding between an organization and its public" (upaya yang sungguh-sungguh, terencana dan berkesinambungnan untuk menciptakan dan mebina saling pengertian antara organisasi dengan publiknya).

Public Relations News memberikan definisi yang lebih luas yaitu :

"The management function which evaluates public attitudes, identifies the policies and procedures of an individual or an organization with the public interest and executes a program of action to earn public understanding and acceptance".

Frank Jefkins memberikan definisi :

"Public relations consist of all forms of planned communication, outwards and inwards, between an organization and its public for the purpose of achieving specific objectives concerning mutual understanding".

Selanjutnya ia mengatakan, bahwa :

Public Relations is "a system of communication to create a goodwill" (suatu sistem komunikasi untuk menciptakan kemauan baik).

Edward L. Bernays mengatakan :

"Public relations has three meanings : (1) information given to the public ; (2) Persuasion directed to the public to modify attitudes and actions of an institution; (3) efforts to integrate attitudes and actions of an institution (public relations mepunyai 
tiga arti, yaitu (1) penerangan kepada masyarakat (2) persuasi untuk mengubah sikap dan tingkah laku masyarakat (3) usaha untuk mengintegrasikan sikap dan perbuatan suatu badan dengan sikap perbuatan masyarakat dan sebaliknya.

Dari berbagai definisi yang dikemukakan para ahli diatas, dapat dilihat bahwa walaupun berbeda-beda ada beberapa kesamaan pokok pikiran, yakni :

1. Public relations merupakan suatu kegiatan yang bertujuan memperoleh goodwill, kepercayaan, saling pengertian, dan citra yang baik dari publik, masyarakat.

2. Sasaran Public Relations adalah menciptakan opini publik yang favourable, menguntungkan semua pihak.

3. Public Relations merupakan unsur yang sangat penting dalam manajmen guna mencapai tujuan yang spesifik dari orgasnisasi/perusahaan.

4. Public Relations adalah suatu usaha untuk menciptakan hubungan yang harmonis antara suatu badan/organisasi dengan masyarakat melalui suatu proses komunikasi timbal balik atau dua arah. Hubungan yagn harmonis ini timbul dari adanya mutual understanding, mutual confidence, dan image yang baik.

Ini semua langkah-langkah yang ditempuh oleh PR untuk mencapai hubungan yang harmonis. Jadi fungsi dari mereka yang bergerak dalam bidang PR ialah menumbuhkan, memupuk dan mendorong sikap dan perilaku yang dapat membantu tercapainya mutual understanding.

\section{Pengertian Krisis}

Umumnya krisis dilihat sebagai suatu situasi atau kejadian yang lebih banyak punya implikasi negaqtif pada organisasi daripada sebaliknya. Fearn-Banks (1996:1) mendefinisikan krisis sebagai "a major occurrence with a potentially negative outcome affecting an organization, company or industry, as well as its publics, products, services or good name”. Biasanya sebuah krisis mengganggu transaksi normal dan kadang mengancam kelangsungan hidup atau keberadaan organisasi. Krisis pada dasarnya adalah sebuah situasi yang tidak terduga, artinya organisasi umumnya tidak dapat menduga bahwa akan muncul krisis yang dapat mengancam keberadaanya. Sebagai ancaman ia harus ditangani secara cepat agar organisasi dapat berjalan normal kembali setelah itu. Untuk itu Holsti melihat krisis sebagai "situations characterized by surprise, high threat to important values, and a short decision time" (Dikutip dalam Guth, 1995 : 125). Krisis membawa keterkejutan dan sekaligus mengancam nilai-nilai penting organisasi serta hanya ada waktu yang singkat untuk mengambil keputusan.

Shrivastava dan Mitroff (1987:6) mendefiniskan krisis perusahan sebagai "events that threaten their most important goals of survival and profitability". Krisis menurut mereka diasosiasikan dengan kerusakan yang berskala luas terhadap kehidupan manusia, lingkungan alam dan institusi social dan politik. Bagi Pauchant dan Mitroff (Guth, 1995 : 125). Contoh yang jelas untuk menjelaskan definisi ini adalah Lumpur Lapindo Sidoardjo yang bermula dari krisis sekitar lokasi perusahaan PT Lapindo Brantas Inc, sampai akhirnya meluas bahkan skala sudah seperti bencana alam karena terlalu luasnya daerah isolasi krisis, dan juga dampak yang ditimbulkan akibat krisis ini sangat besar sekali meluas ke aspek Sosial kemasyarakatan, Ekonomi, Kesehatan, hukum, dan Budaya. Bahkan Presiden RI 
Bapak Soesilo Bambang Yudhoyono cukup direpotkan dengan persoalan pengungsi dan korban Lapindo yang menuntut ganti rugi atas tanah, lahan pertanian dan bangunan mereka.

Krisis juga merupakan "a disruption that physically affects a system as a whole and threaten its basic assumptions, its subjective sense of self, its exixtential core". Menurut mereka, krisis biasanya memiliki tiga dampak, yaitu pertama ancaman terhadap legitimasi organisasi, adanya perlawanan terhadap misi organisasi, dan ketiga, terganggunya cara orang melihat dan menilai organisasi.

Contoh nyata untuk menjelaskan hal ini adalah ketika pesawat Garuda Indonesia jatuh di Yogyakarta beberapa waktu yang lalu. Hal ini merupakan ancaman bagi reputasi Garuda sebagai perusahaan penerbangan no. 1 di Indonesia yang juga adalah perusahaan BUMN. Penilaian masyarakat atau public dapat berubah karena hal ini. Dan tentu saja, Ini merupakan opini public yang tidak menguntungkan bagi PT Garuda Indonesia. Yang terlihat adalah bagaimana Garuda secara cepat mengantisipasi dengan pendekatan media relations yang baik. Walaupun ada kesan mereka sangat hati-hati dalam menyebutkan jumlah penumpang yang tewas dalam peristiwa naas tersebut. Tetapi dapat diperkirakan bahwa reputasinya sebagai perusahaan penerbangan kelas 1 cukup menurun dengan adanya peristiwa tersebut.

Krisis menurut Linke (Linke, 1989:166) juga merupakan suatu ketidaknormalan dari konsekuensi negative yang mengganggu operasi sehari-hari sebuah organisasi. Bagi Linke, krisis mungkin bisa berakibat pada kematian, menurunnya kualitas kehidupan, berkurangnya tingkat kesejahteraan, dan menurunnya reputasi perusahaan. Contoh yang nyata dari peritiwa ini adalah PT Neumont Minahasa Raya yang mengalami msalah dengan penduduk sekitar teluk Buyat karena limbah buangan perusahaan dianggap membahayakan warga sekitar. Ini menunjukkan bahwa keberadaan perusahaan mengganggu ekosistem sekitar dan mengakibatkan menurunnya kualitas kehidupan. Reputasi perusahaan juga berkurang akibat hal ini. Apalagi sejak dikeluarkannya keputusan Mahkamah Agung tentang PT Neumont Minahasa Raya yang dinyatakan tidak bersalah, dan berbuntut pada dibebaskannya Direktur Utama Richard Neiss dari segala tuntutan, menyebabkan warga menjadi resah dan marah. LSM lingkungan hidup pun ikut "berteriak" seolah penantian warga/komunitas sekitar selama 20 bulan kasus ini disidangkan sama sekali tidak berbuah hasil yang manis. Ironis memang, tetapi wajah peradilan Indonesia, ditambah dengan kehadiran Perusahaan PMA dan hukum Indonesia yang bisa ditarik ulur menyebabkan public yang terkena imbas makin tersisih dan hampir tidak memiliki jalan keluar. Bagi PT Neumont crisis is over, tetapi bagi komunitas sekitar, crisis is still out there!.

Bagi Barton, (1993:2) Sebuah krisis adalah peristiwa besar yang tidak terduga yang secara potensial berdampak negative terhadap organisasi dan publiknya. Peristiwa ini mungkin secara cukup berarti merusak organisasi, karyawan, produk dan jasa yang dihasilkan organisasi, kondisi keuangan dan reputasi perusahaan. Untuk menjelaskan krisis ini bisa dilihat melalui produk yang dinilai melanggar aturan label halal misal Ajinomoto beberapa tahun lalu yang diperkirakan mengandung lemak babi. Ini merupakan krisis yang mengancam peredaran produk dan kepercayaan public pada perusahaan,. Jika keuntungan perusahaan menurun, tentu berdampak juga pada kesejahteraan karyawan dan keluarga karyawan. 
Tetapi ada juga yang melihat bahwa krisis tidak selalu mengantar perusahaan pada kebangkrutan. Fink (1986:15 dalam I Gusti Ngurah Putra 1999 : 84) melihat krisis sebagai "an unstable time or state of affairs in which a decive change is implending - either one with the distinct possibility of a highly undesirable outcome or one with distinct possibility of a highly desirable and extremely positive outcome"

Peristiwa yang bisa menjelaskan hal ini adalah Kasus Tylenol yang terkenal dimana tahun 1982, lusinan kapsul Tylenol yang diproduksi Johnson and Johnson terkontaminasi cyanide. Tujuh orang yang meminum kapsul ini tewas seketika ketika meminum obat ini. Ini menciptakan semacam bencana nasional dan krisis internal bagi Johnson and Johnson yang memproduksi kapsul Tylenol ini. Mereka pun menarik kembali produknya dipasaran dengan kerugian biaya yang sangat besar yakni mencapai lebih dari 100 juta dollar. Berangkat dari pengalaman pahit ini Johnson and Johnson berbenah diri dan melakukan berbagai kampanye PR yang akhirnya dapat memulihkan citra perusahaan mereka kembali.

Selain itu Webster (dalam I Gusti Ngurah Putra 1999: 85) mendefinisikan krisis sebagai titik balik (turning point) untuk menuju keadaan lebih baik atau lebih buruk (turning point for the better or worse) jadi lebih dari suatu situasi ini, mungkin perusahaan atau organisasi dapat menjadi lebih baik atau lebih buruk.

Apakah krisis akan menjadikan organisasi menjadi lebih baik atau lebih buruk sangat tergantung pada bagaimana pihak manajemen mempersepsikan dan kemudian merespon situasi tersebut atau sangat tergantung pada pandangan, sikap atau tindakan yang diambil terhadap krisis tersebut (Hardjana, 1998 : 15). Jika manager sebuah organisasi melihat lingkungan organisasinya potensial menghasilkan bencana, maka ia akan melihat pentingnya perencanaan krisis sebagai bahan dari perencanaan strategis dan mengalokasikan sumberdaya yang memadai untuk itu. (Wisenblit 1989:33 dalam I Gusti Ngurah Putra 1999:85).

\section{Manajemen Krisis}

Walaupun sebuah krisis dapat menjadi titik balik bagi semakin baiknya sebuah keadaan, tampaknya hampir tidak ada pimpinan organisasi yang mengharapkan situasi demikian untuk memperbaiki keadaan. Atau paling tidak organisasi tidak ingin mengalami suatu krisis. Karena mereka berharap demikian, mereka lupa bahwa krisis dapat saja terjadi pada perusahaan mereka, sehingga banyak pengelola perusahaan yang tidak menyadari pentingnya suatu perencanaan khusus untuk menghadapi dan menangani krisis yang mungkin muncul.

Wisenblit (1989 : 33) menyatakan :

Too often succesfull companies are complacent. Management reads about other companies disaster with an it-cant's -happen-here attitude. They simply do not see the risk potential. Part of this because people are generally reluctant to think about crisis. But, thinking negatively - thinking of the worst possible disasters that could befall the company and planning for them - is the basis for crisis management planning"

\section{Tahapan Krisis}

Krisis tidak bergerak spontan, ia selalu diawali dengan gejala. Yang kadang tidak terlihat atau terdeteksi oleh perusahaan. Sehingga kurang tepat jika ada statement dari perusahaan atau organisasi yang mengatakan bahwa krisis di 
perusahaan mereka datangnya tiba-tiba. Mengapa ? karena krisis bergerak dari satu tahap ke tahap lainnya. Ketika tidak diantisipasi pada tahap awal, ia akan makin meluas dan merugikan organisasi dan publiknya.

Tahapan krisis atau lazimnya disebut sebagai anatomi krisis memiliki arti yang berbeda-beda oleh sebagian ahli. Oleh Fink (1986) dan Sturges, dkk (1991) menyatakan ada empat fase yang dilewati oleh sebuah krisis. Sedangkan FearnBanks (1996) menyebutkan lima fase dari sebuah krisis. Namun secara garis besar kedua pendapat ini tidak menunjukkan perbedaan yang cukup berarti. GonzalesHerrero dan Pratt (1995) menganalogikan krisis seperti tahapan kehidupan : kehamilan, kelahiran, pertumbuhan, kedewasaan, dan penurunan (kematian).

Tahap pertama adalah tahap "Crisis build up" (Sturges, dkk 1991) atau pedromal periods (Fink, 1986). Pada fase ini gejala atau tanda-tanda krisis mulai muncul. Jika gejala ini cepat dikenali dan diatasi maka terjadi crisis abortion (Gonzales - Herrero \& Pratt, 1995). Pada tahap ini, Public Relations perlu melakukan strategi berikut ini :

1. Melakukan pemantauan terhadap lingkungan untuk mengetahui kecenderungan-kecenderungan yang berkembang yang mungkin mempengaruhi organisasi

2. Mengumpulkan data masalah yang potensial menimbulkan kesulitan bagi organisasi

3. Mengembangkan strategi komunikasi dan berkonsentrasi untuk mencegah munculnya krisis. Jika perusahaan dapat cepat bergerak mengatasi ini, maka besar kemungkinan tidak akan terjadi krisis.

Tahap kedua, "Crisis Breakout" atau Acute Crisis, yakni telah terjadi kejadian yang menyebabkan perusahaan mulai mengalami kerugian. Tahap ini dikatakan Fink sebagai tahap the pint of no return. Atau tahap krisis actual. Dalam tahap ini kerusakan benar-benar telah terjadi. Jika kemudian perusahana tidak dapat mengatasinya, maka kerusakan lanjutan hanyalah masalah waktu. Tahap inilah korban-korban mulai terlihat. Bisa dalam bentuk kematian, kerusakan property, kerusakan lingkungan dan sebagainya. Pada tahap inilah manajemen perusahaan menghadapi ujian yang sangat berat. Penanganan dalam tahap ini lebih sulit dibanding penanganan pada fase sebelumnya. Pada awalnya, umumnya perusahaan mungkin mencoba menolak adanya krisis, tetapi pada akhirnya organisasi harus menyadari dan mengakui bahwa pada tahap ini krisis memang benar-benar telah terjadi dan tidak bisa mereka hindari.

Tahap ketiga yaitu "abatement" (peredaan) atau 'chronic crisis stage”. Pada tahap ini sering juga disebut sebagai tahap transisi atau' clean up stage”. Organisasi berusaha untuk menangani atau berusaha kembali dan melakukan perubahanperubahan penting. Saat ini perusahaan mungkin harus menyelesaikan masalah tuntutan berbagai pihak yang antara lain dapat berbentuk pemberian kompensasi, ganti rugi, cash and carry, dan masalah-masalah hukum lainnya. Tahap ini dapat berlangsung sangat lama, lebih lama dari tahap krisis sesungguhnya. Karena untuk menentukan ganti rugi mungkin tidak begitu gampang. Apalagi kalau melalui proses peradilan. Belum lagi yang harus dilayani begitu banyak. Contoh nyata dari krisis tahap ketiga ini adalah PT Neumont Minahasa Raya (MNR) yang menempuh 
20 bulan proses peradilan yang panjang, tetapi toh berujung pada ketidak puasan warga sekitar dan LSM lingkungan hidup.

Tahap keempat, "crisis resolution stage" atau "termination stage", yaitu ada tanda-tanda penyelesaian akhir yang menandakan bahwa krisis tidak lagi merupakan ancaman bagi organisasi. Dalam hal ini ibarat orang sakit, perusahaan sudah menunjukkan proses kesembuhan. Jadi, krisis sudah mulai reda. Namun demikian krisis dapat kembali muncul. Pada tahap ini perusahaan harus tetap ekstra hatihati. Pada tahap ini perusahaan harus menaruh perhatian pada berbagai publiknya. Melanjutkan pemantauan terhadap masalah sampai intensitas masalah yang muncul berkurang, melanjutkan perhatian pada media dengan mensupport informasi yang dibutuhkan oleh media terkait dengan berbagai tindakan yang dilakukan oleh manajemen, mengevaluasi rencana penanganan krisis, jika memang ada, menjadikan umpan balik yang ada sebagai amsukan untuk perencanaan krisis dimasa mendatang dan mengembangkan strategi komunikasi jangka panjang untuk mengurangi kerusakan yang disebabkan oleh krisis yang terjadi (Gonzales-Herrero \& Pratt, 1995 : 29)

Krisis jarang terjadi karena satu factor, umumnya terjadi karena akumulasi dari factor-faktor yang lain juga. Penyebab krisis dapat dikategorikan menjadi :

1. Karena kesalahan manusia (human error)

2. Karena kegagalan teknologi

3. Karena alasan social (kerusuhan, perang, sabotase, teroris, dll)

4. Berkaitan dengan bencana alam (natural disaster)

5. Karena ketidakbecusan manajemen

(Shrivastava \& Mitroff, 1987; Sen \& Egelhoff, 1991 : 79)

\section{Peran PR dalam Krisis}

Krisis harus direspon dengan baik oleh perusahaan, biasanya dapat dilakukan melalui Public Relations yang menjembatani antara organisasi dengan publiknya. Disamping itu, PR adalah fungsi manajemen yang mengidentifikasi sikap public. Beranjak dari hekikat PR inilah maka kita dapat meresponi setiap krisis yang datang.

Pertama, libatkan manajemen secara langsung dalam krisis. Ini berarti juga menolong memperkecil stress yang dialami oleh senior management dalam mengambil keputusan tentang penanggulangan krisis. PR dapat membuat laporan secara periodic mengenai progress dari krisis yang terjadi bahkan sekaligus melibatkan manajemen melalui kunjungan ke lokasi kejadian. Selain itu jika terjadi korban misalnya untuk kasus jatuhnya pesawat terbang bisa mengajak senior management untuk mendatangi pemakaman kru dan penumpang pesawat yang jatuh, kompensasi keuangan yang diberikan secara langsung, pembuatan yayasan untuk menangani anak-anak korban bencana Lumpur Lapindo, misalnya, dan sebagainya.

Kedua, Tindakan komunikasi yakni apa yang harus dikatakan oleh perusahaan mengenai krisis. Dalam hal ini informasi harus betul-betul dikemas dengan baik. Kebutuhan informasi menjadi sangat tinggi. Karena itu informasi harus cepat tetapi juga akurat dan selalu di update. Ini merupakan prioritas utama. Media harus digandeng untuk memberikan informasi yang tepat dan akurat pada public dan masyarakat secara luas. Informasi harus terpusat dan satu pintu, untuk 
memudahkan lalu lintas informasi, karena itu perlu dibuat crisis center atau emergency centre dengan staf yang terlatih.

Public Relations harus berperan dalam memberitahukan public tentang apa yang terjadi, apa yang sedang dan akan dilakukan perusahaan dan apa yang harus di lakukan oleh public. Ini merupakan pendekatan simbolik yang harus ditempuh organisasi (Gould \& Kelly, 1974 dalam Putra, 1999: 96). Bahkan pada waktu krisis telah selesai ditanggulangi, peran PR adalah memperbaiki hubungan dan posisi perusahaan di masyarakat secara umum dan stakeholders secara khusus. Ini dapat dilakukan dengan pertemuan-pertemuan penting dengan pemerintah, karyawan dan keluarganya, media internal perusahaan, media massa dan melanjutkan strategi komunikasi jujur dan terbuka.

Dalam hal ini kedua tindakan tadi harus mencerminkan 2 (dua ) hal. Pertama, tanggungjawab yang tinggi dari pihak manajemen organisasi terhadap harkat atau nilai-nilai kemanusiaan. Upaya pencarian kambing hitam atau pihak ketiga, menghindari media, berdiam diri alias off the record, ketidakjujuran, manipulasi data, sebaiknya dihindari karena justru berujung pada jatuhnya reputasi perusahaan. Kedua, komunikasi yang dibangun atas dasar kejujuran dalam upaya membangun hubungan yang baik dan kepercayaan public terhadap niat baik organisasi. Keduanya tidak dapat dipisahkan satu sama lain, dan harus menjadi wilayah perhatian dari Public Relations. Seperti dikatakan oleh Sen \& Egelhoff (1991:81) : "It is always important to show concern for the victims. However, this must be done in a credible way. Statement have to be backed by actions. Good intentions have to be actually implemented".

\section{KESIMPULAN}

Krisis tidak bisa menjadi pilihan yang dapat ditolak oleh organisasi. Krisis hidup dan terus berkembang seiring dengan lajunya organisasi dan lajunya komunikasi organisasi tersebut. Ketika krisis muncul maka peluangnya adalah memanage krisis tersebut menjadi lebih terkendali. Public Relations semestinya hadir sebagai bagian dalam organisasi yang menjembatani antara organisasi dengan publiknya. Karena itu ketika orang mengatakan bahwa krisis adalah peluang Public Relations (PR) untuk tampil menjadi pemadam kebakaran, saya tidak setuju dengan statement tersebut. PR hadir bukan sebagai pemadam kebakaran seperti jargon-jargon yang beredar tentang hal ini, tetapi PR adalah kebutuhan dari perusahaan untuk terus bergerak maju.

Keputusan PR bukanlah keputusan yang mengandalkan intuisi belaka melainkan berdasar pada keputusan top manajemen dengan dasar pertimbangan dari Public Relations, dimana posisi PR seharusnya berdekatan atau memiliki akses langsung dengan top manajemen. Sehingga ketika PR berperan sebagai mata, telinga dan corong dari perusahaan, ia tidak bergerak sendiri melainkan bergerak bersama seluruh komponen organisasi tersebut. Terlebih jika krisis tengah melanda. Karena itu peran PR yang dewasa ini lebih ditekankan pada membantu pemecahan masalah di perusahaan, menjadi suatu keharusan.

Manajemen Krisis (Crisis Management) merupakan area keahlian yang harus dimiliki oleh setiap PR, yang berorientasi kepada masa depan dan mencoba mengantisipasi kejadian yang dapat mengganggu hubungan-hubungan penting. 
PR memiliki peran penting dalam merencanakan program persiapan krisis, manajemen krisis itu sendiri pada waktu terjadi krisis dan strategi setelah krisis selesai ditanggulangi.

Ketika krisis terjadi ada hal-hal yang seharusnya dilakukan oleh Public Relations antara lain mengemas informasi terhadap public dapat dilakukan dengan cara :

\section{Instructing Information}

Informasi yang pada dasarnya berisi petunjuk atau pedoman apa yang harus dilakukan oleh public atau bagaimana public bertindak dalam krisis. Misalnya pada kasus likuidasi bank. Public yang disasar bukan hanya public eksternal tetapi juga internal, yakni karyawan, keluarga karyawan, direksi, pemegang saham/investor.

\section{Adjusting Information}

Informasi yang memungkinkan public untuk mengatasi masalah-masalah emosional mereka Misalnya pada kasus jatuhnya pesawat terbang, keluarga penumpang perlu di beri informasi yang jelas dan akurat tentang kondisi terkini atau perkembangan kecelakaan tersebut. Tetapi tentunya isi pesannya berbeda, karena dibutuhkan emphaty yang luar biasa dalam hal ini.

\section{Internalizing Information}

Informasi yang akan diserap khalayak yang pada akhirnya akan membentuk penilaian public terhadap sebuah organisasi dalam jangka panjang. Isi komunikasi biasanya menyangkut inti krisis yang sedang dihadapi organisasi. Langkah-langkah yang sedang ditempuh perusahaan, dan sebagainya. Publik perlu mengetahui hal ini. Karena ini menyangkut trust public pada perusahaan.Biasanya Public Relations akan menggelar jumpa pers atau press conference dan mengundang media untuk menghadiri, kemudian ada tim krisis dari crisis centre perusahaan dan kemudian narasumber utama dari pimpinan perusahaan dan juga keluarga korban (kalau ada) dan tentunya Public Relations tetap ada untuk memantau dan membuat report atas krisis tersebut. Dan satu hal yang tidak bisa dihindari dan masih jarang dilakukan PR di Indonesia (kecuali PR dari corporate yang besar) adalah HP atau mobile phone harus selalu aktif 24 (dua puluh empat) jam. Hal ini penting karena media percaya pada perusahan melalui Public Relations dan dari hubungan mutual understanding ini akan tercipta mutual benefit yang berguna bagi kelangsungan hidup organisasi sebagai suatu organisme social yang membutuhkan lingkungan internal dan eksternalnya. Yang diperlukan PR adalah kemampuan untuk melakukan komunikasi yang jujur dan terbuka yang berlangsung two way symmetrical (dua arah dan simetris) dengan publiknya. Sehingga aktivitas media relations termasuk ketrampilan untuk menjalin hubungan yang harmonis dengan pers, harus menjadi bagian yang terintegrasi dalam lingkup pekerjaan Public Relations, bukan hanya ketika krisis terjadi, maka wartawan pun dilirik.

\section{DAFTAR PUSTAKA}

Fearn-Banks, K. 1996. Crisis Communication : A Case book Approach. Mahwah, NJ: Lawrence Erlbaum

Fink, S. 1986. Crisis Management : Planning for the inevitable,. New York : Amacom 
Guth, D.W. 1995. "Organizational Crisis Experience and Public Relations Roles". Public Relations Review, Vol, 21 (2)

Gonzales-Herrero, A and Pratt, C.B. 1995. How to Manage a crisis before or whenever - Public Relations Quaterly. Spring

Jurnal Ilmu Komunikasi. 1998. Vol.II/Oktober

Panuju, Redi. 2002. Krisis Public Relations. Yogyakarta: Pustaka Pelajar

Putra, I Gusti Ngurah. 1999. Manajemen Hubungan Masyarakat, Yogyakarta: Penerbitan Universitas Atmajaya

Wasesa, Silih Agun. 2005 Strategi Public Relations. Jakarta: PT Gramedia Pustaka Utama 